\title{
IMPACT OF THE SHOCKS FROM NYSE ON THE ROMANIAN CAPITAL MARKETS
}

\author{
Razvan Stefanescu \\ rstefanescu@ugal.ro \\ Ramona Dumitriu \\ rdumitriu@ugal.ro \\ "Dunarea de Jos" University of Galati, Romania
}

\begin{abstract}
Since the adhesion to European Union, the influence of the international financial markets on the Romanian capital market intensified. In this paper we investigate the impact of the shocks from New York Stock Exchange on the Bucharest Stock Exchange evolution. We found that a significant proportion of the shocks from Bucharest Stock Exchange could be associated to the sharp fluctuations of the stock prices that occurred on the United States capital market.
\end{abstract}

Keywords: Capital Markets, Emerging Market Integration, Shocks.

JEL classification codes: F30, G14, G15.

\section{Introduction}

The linkages between emerging and developed capital markets are among the topics of international finance literature. The study of the stock markets co-movement could be useful in identifying the opportunities of the international portfolio diversification or in the financial stability assessment.

The efficiency of strategies to reduce the risks associated to share prices through international portfolio diversification depends on the degree of linkages among the stock markets. When the capital markets are highly correlated, the diversification is useless. Until 1980s many empirical researches found low correlations between developed and emerging markets (Grubel, 1968; Levy \& Sarnat, 1970; Solnik, 1974). However, in the last decades, the liberalization of capital markets combined with the effects of globalization lead to the increase of the emerging markets integration in the world capital markets (Goldstein \& Michael 1993; Chowdhury, 1994; Bekaert \& Harvey, 1998; Bekaert \& Harvey, 2000; Dunis \& Shannon, 2005).

The relationships between international capital markets could affect the financial stability of a country. In specific circumstances, especially during financial crises, these linkages are responsible for the propagation of instability from a country to another one (Forbes \& Rigobon, 2002; Dungey \& Martin, 2007; Bekaert et al., 2011).

In this paper we approach the influence of the New York Stock Exchange (NYSE) on the much smaller Bucharest Stock Exchange (BSE) between January 2007 and March 2015. This period of time was marked, for both capital markets, by a significant instability caused mainly by the recent global crisis. In the case of BSE we have to also take into account the changes induced by Romania's adhesion to European Union, in January 2007, which intensified BSE integration in the world financial markets (Dumitriu \& Stefanescu, 2014). In general, the linkages between capital markets are assessed by the study of the return correlations or by the volatility spillover analysis. In this article we identify the shocks from BSE that could be associated to the sharp fluctuations that occurred on NYSE. The results could indicate if the investors from BSE were sensitive to the shocks from NYSE. The rest of the paper is organized as it follows: the second part describes the data and methodology employed to identify and analyze shocks from both stock markets, the third part presents the empirical results and the fourth part concludes.

\section{Data and Methodology}

In this investigation about the impact of the shocks from NYSE on BSE we employ daily closing values of one index from United States (the well known S\&P 500) and five indexes from Romanian capital market (BET, BET-C, BET-FI, BET-XT and BET-NG) presented in the Table 1. For all indexes, except BET-C which wasn't calculated anymore by BSE since July 2014, we use data from January 2007 
International Conference "Risk in Contemporary Economy" ISSN-L 2067-0532 ISSN online 2344-5386 XVIth Edition, 2015, Galati, Romania,

"Dunarea de Jos" University of Galati - Faculty of Economics and Business Administration

to March 2015. The closing values of the six indexes are provided by Yahoo! Finance for S\&P 500 and by BSE, for the other five indexes.

Table 1. Indexes from BSE employed in the investigation

\begin{tabular}{|c|l|c|}
\hline Index & \multicolumn{1}{|c|}{ Composition } & Period of time \\
\hline BET & $\begin{array}{l}- \text { shares of most liquid 10 } \\
\text { companies listed on the BSE } \\
\text { regulated market }\end{array}$ & \\
\hline BET-C & $\begin{array}{l}- \text { shares of all the big companies } \\
\text { listed on BSE excepting the } \\
\text { investment funds (SIFs) }\end{array}$ & January 2007 - June 2014 \\
\hline BET-FI & $\begin{array}{l}- \text { shares of the five investment } \\
\text { funds (SIFs) }\end{array}$ & January 2007 - March 2015 \\
\hline BET-XT & $\begin{array}{l}- \text { shares of the most liquid 25 } \\
\text { shares traded on BSE, including } \\
\text { SIFs }\end{array}$ & January 2007 - March 2015 \\
\hline BET-NG & $\begin{array}{l}- \text { shares of companies which have } \\
\text { the main business activity located } \\
\text { in the energy sector and the related } \\
\text { utilities }\end{array}$ & January 2007 - March 2015 \\
\hline
\end{tabular}

Source: Bucharest Stock Exchange

The Figure 1 presents the evolution of S\&P 500 between January 2007 and March 2015. After a dramatic decline during the most acute phase of the crisis, S\&P 500 experienced an ascendant trend since 2009.

The evolutions of the five indexes are presented in the Figure 2. All of them followed trends that were quite closed to the trend of S\&P 500 .

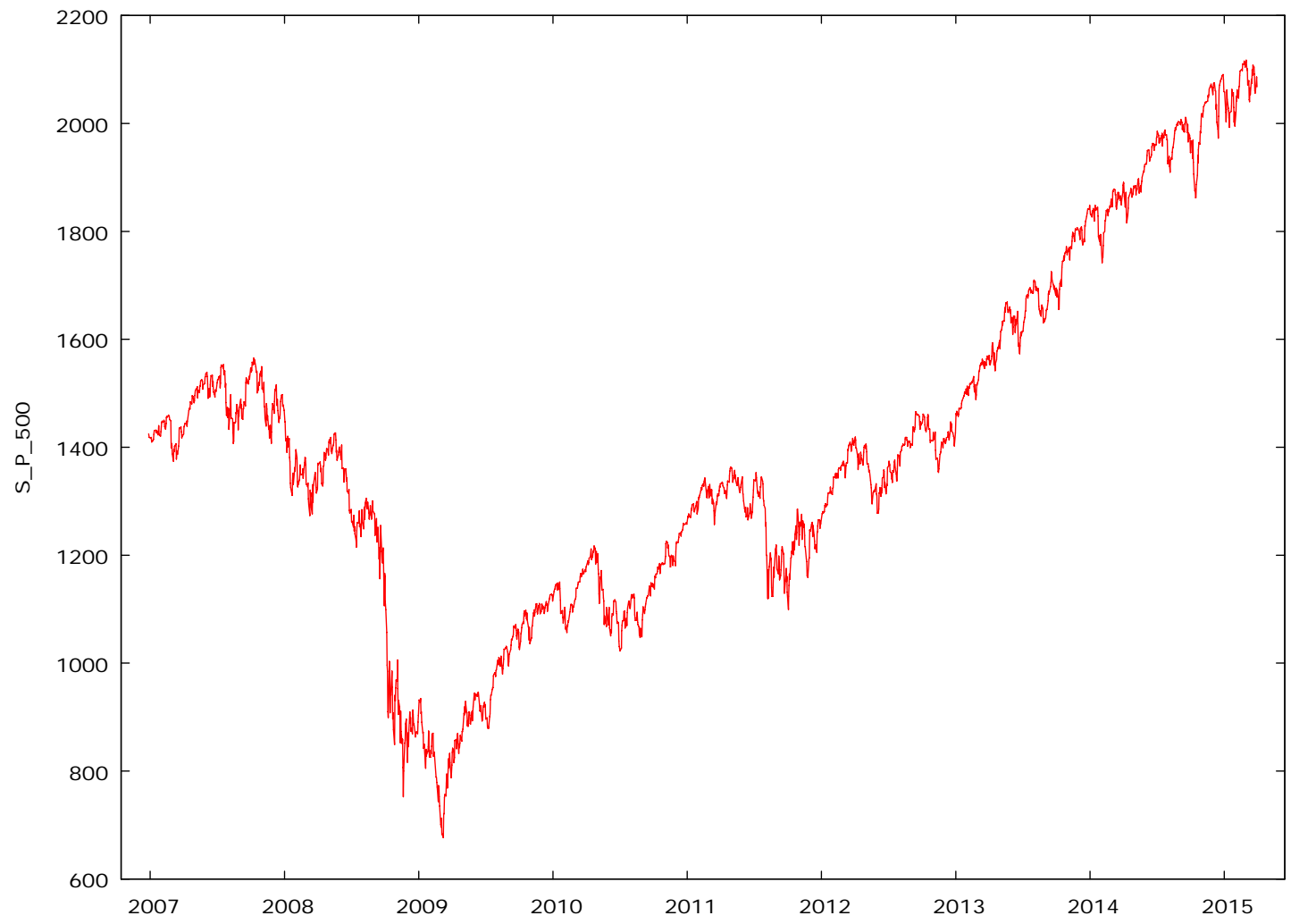

Figure 1. Evolution of S\&P 500 between January 2007 and March 2015

Source of data: Yahoo! Finance 

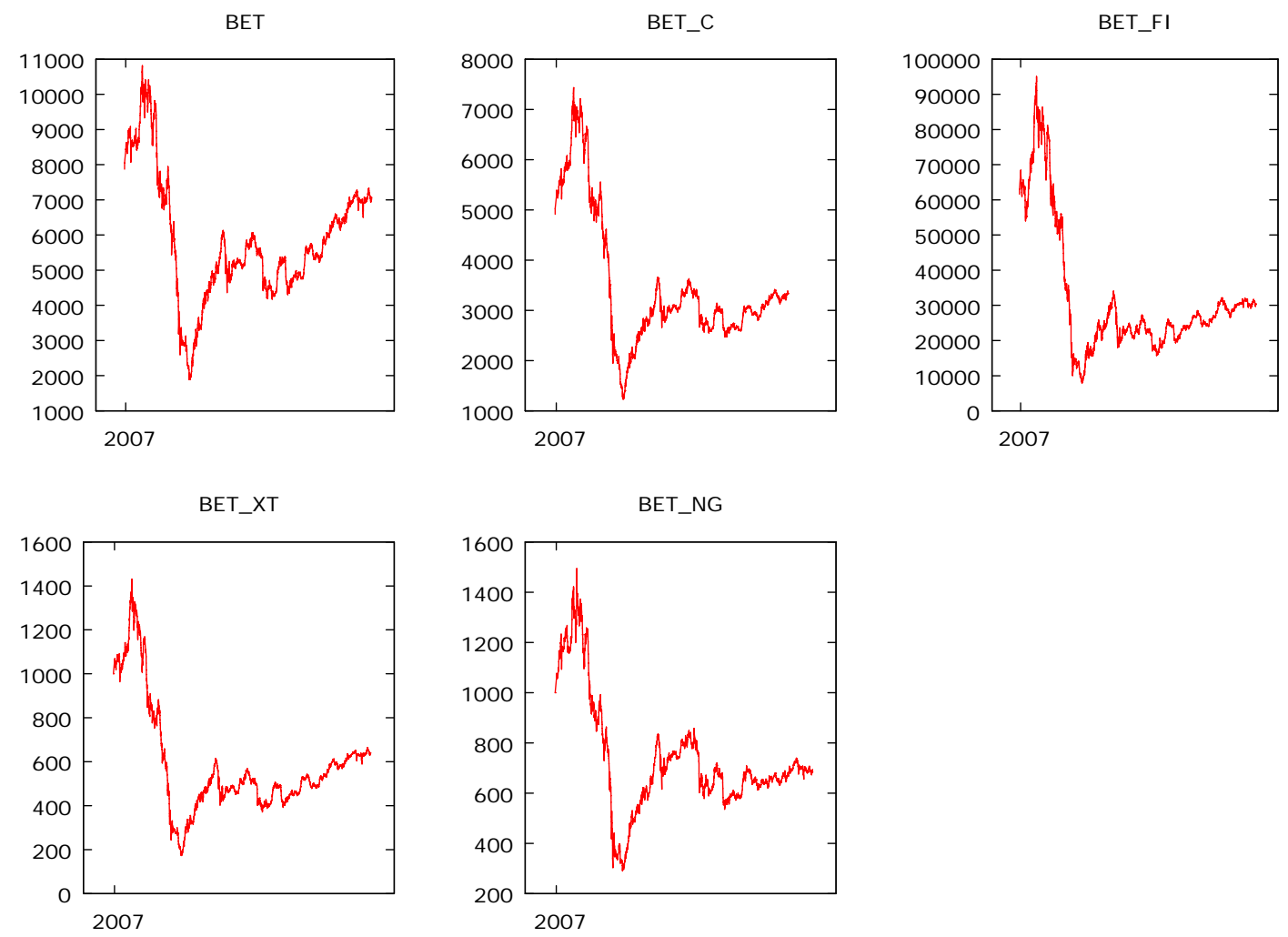

Figure 2. Evolutions of the BSE indexes used in the investigation

Source of data: Bucharest Stock Exchange

We identify the shocks occurred in the evolutions of the six indexes employing the method used by Lasfer et al. (2003). We start by computing the raw return of each index $\left(\mathrm{r}_{\mathrm{i}, \mathrm{t}} \mathrm{t}\right.$ by the formula:

$$
r_{i, t}=\frac{P_{i, t}-P_{i, t-1}}{P_{i, t-1}} * 100
$$

where $P_{i, t}$ and $P_{i, t-1}$ are the closing values of the index $i$ on the days $t$ and $t-1$, respectively. The positive shocks are identified by the condition:

$$
r_{i, t}^{+}>\mu_{i, t}^{I r^{+}}+2 \times \sigma_{i, t}^{I r^{+}}
$$

where:

$-r_{i, t}^{+}$is the return of the index $\mathrm{i}$, corresponding to a positive shock that occurs in the day $\mathrm{t}^{+}$;

- $\mu_{i, t}^{I r^{+}}$is the average daily returns for a period of time Ir $^{+}$that starts 60 days before the day $\mathrm{t}^{+}$, and ends 11 days before the day $\mathrm{t}^{+}$;

- $\sigma_{i, t}^{I r^{+}}$is the standard deviation of returns for the period $\mathrm{Ir}^{+}$.

The negative shocks are identified by the condition:

$$
r_{i, t}^{-}<\mu_{i, t}^{I r^{-}}-2 \times \sigma_{i, t}^{I r^{-}}
$$

where:

- $r_{i, t}^{-}$is the return of the index $\mathrm{i}$, corresponding to a negative shock that occurs in the day $\mathrm{t}^{-}$;

- $\mu_{i, t}^{I r^{-}}$is the average daily returns for a period of time Ir- that starts 60 days before the day $\mathrm{t}^{-}$, and ends 11 days before the day $\mathrm{t}$;

- $\sigma_{i, t}^{I r^{-}}$is the standard deviation of returns for the period Ir. 
We consider that a shock from NYSE that precedes a shock from BSE with less than two days is susceptible to have a significant impact on Romanian capital market (we have to take into consideration the gap between the closing hours from the two stock exchanges).

\section{Empirical Results}

The Table 2 reports the numbers of positive and negative shocks identified for the six indexes. For S\&P 500 the negative shocks are more numerous than the positive ones, while for the BSE indexes the proportions are quite equilbrated.

Table 2. Numbers of positive and negative shocks associated for the six indexes

\begin{tabular}{|c|c|c|}
\hline Index & Positive shocks & Negative shocks \\
\hline S\&P 500 & 60 & 99 \\
\hline BET & 61 & 71 \\
\hline BET-C & 52 & 66 \\
\hline BET-FI & 71 & 75 \\
\hline BET-XT & 67 & 74 \\
\hline BET-NG & 77 & \\
\hline
\end{tabular}

The number and percentage of positive shocks from BSE associated to NYSE positive shocks are presented in the Table 3. The smallest percentage (13.46\%) was obtained for BET-C, while the largest (24.59\%) occurred for BET.

Table 3. Positive shocks from BSE associated to NYSE positive shocks

\begin{tabular}{|c|c|c|c|c|c|}
\hline Index & Number of positive shocks & \multirow{2}{*}{$\begin{array}{c}\text { Percentage of } \\
\text { total positive }\end{array}$} & \multicolumn{3}{|c|}{ Days related to a NYSE positive } \\
\cline { 4 - 6 } & NYSE positive shocks & shocks from BSE & $\mathrm{t}^{+}$ & $\mathrm{t}^{+}+1$ & $\mathrm{t}^{+}+2$ \\
\hline BET & 15 & $24.59 \%$ & 4 & 7 & 4 \\
\hline BET-C & 7 & $13.46 \%$ & 4 & 2 & 1 \\
\hline BET-FI & 14 & $19.72 \%$ & 8 & 5 & 1 \\
\hline BET-XT & 14 & $20.90 \%$ & 6 & 6 & 2 \\
\hline BET-NG & 13 & $16.88 \%$ & 6 & 5 & 2 \\
\hline
\end{tabular}

The Table 4 reports the number and percentage of negative shocks from BSE associated to NYSE negative shocks. The smallest percentage $(30 \%)$ occurred for BET-C, while the largest percentage $(45.45 \%)$ was obtained for BET-FI.

Table 4. Negative shocks from BSE associated to NYSE negative shocks

\begin{tabular}{|c|c|c|c|c|c|}
\hline Index & \multirow{2}{*}{$\begin{array}{c}\text { Number of negative shocks } \\
\text { from BSE associated to NYSE }\end{array}$} & \multirow{2}{*}{$\begin{array}{c}\text { Percentage of } \\
\text { total negative } \\
\text { negative shocks }\end{array}$} & \multicolumn{3}{|c|}{ Days related to a NYSE negative } \\
\cline { 4 - 6 } & shocks from BSE & $\mathrm{t}$ & $\mathrm{t}+1$ & $\mathrm{t}+2$ \\
\hline BET & 25 & $35.21 \%$ & 7 & 16 & 2 \\
\hline BET-C & 21 & $30.00 \%$ & 8 & 11 & 2 \\
\hline BET-FI & 30 & $45.45 \%$ & 14 & 13 & 3 \\
\hline BET-XT & 33 & $44.00 \%$ & 14 & 17 & 2 \\
\hline BET-NG & 31 & $41.89 \%$ & 12 & 16 & 3 \\
\hline
\end{tabular}




\section{Conclusions}

In this paper we approached the influence of the shocks from NYSE on BSE. We found that significant proportions of BSE shocks could be associated to the sharp fluctuations of NYSE. We could not reject the possibility that some of the BSE shocks were not necessarily caused by NYSE shocks that preceded them with less than two days. However, the results suggest that investors from BSE are quite sensitive to the sharp fluctuations of NYSE.

Our investigation indicate that proportions of BSE negative shocks associated to negative shocks of NYSE are larger than in the case of positive shocks. Such results could be explained by the fact that investors are more sensitive to the bad news than to the good news. The most sensitive BSE index to the negative shocks of NYSE was BET FI, which is computed based on the shares of the five investment funds. In general, investors in these shares react promptly to the bad news from international markets.

This investigation could be extended by taking into consideration the shocks from other international financial markets.

\section{References}

1. Adrangi, B., Raffiee, K. \& Shank, T. M. (2003), "Regional financial crises and equity market reactions: The case of East Asia", International Journal of Business, 8(1).

2. Aslanidis, N. \& Savva, C. S. (2011), "Are There Still Portfolio Diversification Benefits In Eastern Europe? Aggregate Versus Sectoral Stock Market Data", Manchester School, 79(6), pp. 1323-1352.

3. Beirne, J., Caporale, G. M., Schulze-Ghattas, M. \& Spagnolo, N. (2009), "Volatility spillovers and contagion from mature to emerging stock markets", CESifo Working Paper No. 2545

4. Bekaert, G., \& Harvey, C. R. (1995), "Time varying world market integration", The Journal of Finance, 50(2), pp. 403-444

5. Bekaert, G., \& Harvey, C. R. (1998), “Capital flows and the behavior of emerging market equity returns”, NBER Working Paper 6669.

6. Bekaert, G., \& Harvey, C. R. (2000), "Foreign speculators and emerging equity markets", The Journal of Finance, 55(2), pp. 565-613.

7. Bekaert, G., Ehrmann, M., Fratzscher, M. \& Mehl, A. J. (2011), “Global crises and equity market contagion”, NBER Working Paper No. 17121

8. Caporale, G. M., Serguieva, A., \& Wu, H. (2009), "Financial contagion: evolutionary optimization of a multinational agent-based model", Intelligent Systems in Accounting, Finance and Management, 16(1-2), pp. 111-125.

9. Chelley-Steeley, P., Lambertides, N. \& Savva, C. S. (2013), "Illiquidity shocks and the comovement between stocks: new evidence using smooth transition", Journal of Empirical Finance, 23, 1-15.

10. Chowdhury, A. R. (1994), "Stock market interdependencies: evidence from the Asian NIEs", Journal of Macroeconomics, 16(4), pp. 629-651.

11. Daniel, K., Hirshleifer, D. \& Teoh, S. H. (2002), "Investor psychology in capital markets: Evidence and policy implications", Journal of Monetary Economics, 49(1), pp. 139-209.

12. Dumitriu, R. \& Stefanescu, R. (2013), "Reactions to Shocks of the Romanian Companies Stock Prices", International Conference of Scientific Paper AFASES 2013 Brasov, 23-25 May 2013

13. Dumitriu, R. \& Stefanescu, R. (2014), "Volatility Transmission from S\&P 500 to the Bucharest Stock Exchange Indexes", Available at SSRN: http://ssrn.com/abstract=2478250

14. Dungey, M. \& Martin, V. L. (2007), "Unravelling financial market linkages during crises", Journal of Applied Econometrics, 22(1), pp. 89-119.

15. Dunis, C. L. \& Shannon, G. (2005), "Emerging markets of south-east and central Asia: Do they still offer a diversification benefit?", Journal of Asset Management, 6(3), pp. 168-190.

16. Forbes, K. J. \& Rigobon, R. (2002), "No contagion, only interdependence: measuring stock market comovements", The Journal of Finance, 57(5), pp. 2223-2261.

17. Goldstein, M. \& Mussa, M. (1993), "The Integration of World Capital Markets", International Monetary Fund Working Paper No. 93/95.

18. Grubel, H. G. (1968), "Internationally diversified portfolios: welfare gains and capital flows", The American Economic Review, pp. 1299-1314.

19. Guidi, F. \& Ugur, M. (2014), "An analysis of South-Eastern European stock markets: Evidence on cointegration and portfolio diversification benefits", Journal of International Financial Markets, Institutions and Money, 30, pp. 119-136.

20. Hassene, B. M. B. (2012), "International Financial Market's Integration and Modelling Returns of Risky Assets", Journal of Modern Accounting and Auditing, 8(7), pp. 1042-1051.

21. Hourvouliades, N. L. (2009), "International portfolio diversification: evidence from European emerging markets", European Research Studies, 12(4), pp. 55-78.

22. Huyghebaert, N. \& Wang, L. (2010), "The co-movement of stock markets in East Asia: Did the 1997-1998 Asian financial crisis really strengthen stock market integration?", China Economic Review, 21(1), pp. 98-112. 
International Conference "Risk in Contemporary Economy" ISSN-L 2067-0532 ISSN online 2344-5386 XVIth Edition, 2015, Galati, Romania,

"Dunarea de Jos" University of Galati - Faculty of Economics and Business Administration

23. Lasfer, M. A., Melnik, A. \& Thomas, D. C. (2003), "Short-term reaction of stock markets in stressful circumstances", Journal of Banking \& Finance, 27(10), pp. 1959-1977

24. Lee, H. Y. (2011), "Contagion in international stock markets during the sub prime mortgage crisis", International Journal of Economics and Financial Issues, 2(1), pp. 41-53

25. Levy, H. \& Sarnat, M. (1970), "International diversification of investment portfolios", The American Economic Review, pp. 668-675.

26. Phylaktis, K. \& Ravazzolo, F. (2005), "Stock market linkages in emerging markets: implications for international portfolio diversification", Journal of International Financial Markets, Institutions and Money, 15(2), pp. 91-106.

27. Royfaizal, R. C., Lee, C. \& Azali, M. (2009), "ASEAN-5+ 3 and US Stock Markets Interdependence Before, During and After Asian Financial Crisis", International Journal of Economics and Finance, 1(2).

28. Shachmurove, Y. (2000), "Portfolio Analysis of Major Eastern European Stock Markets" International Journal of Business, 5(2), 1-28.

29. Sharma, A. \& Seth, N. (2012), "Literature review of stock market integration: a global perspective", Qualitative Research in Financial Markets, 4(1), 84-122.

30. Solnik, B. H. (1995), "Why not diversify internationally rather than domestically?", Financial Analysts Journal, 51(1), pp. 89-94.

31. Syriopoulos, T. (2007), "Dynamic linkages between emerging European and developed stock markets: Has the EMU any impact?", International Review of Financial Analysis, 16(1), pp. 41-60. 